\title{
Настава страних језика на раном узрасту: приказ модела наставе и наставног плана и програма у Србији
}

\author{
Дуња Д. Бранков* \\ Универзитет у Београду, Филолошки фракултет
}

\section{Кључне речи:}

вишејезичност

основно школовање језичка образовна политика

\begin{abstract}
Апстракт
Теоријски део рада представља каква је настава у погледу учења страних језика у раном узрасту у свету, али првенствено у Европи, Србији и у земљама на територији бивше републике Југославије. Један од главних циљева рада јесте да се установи да ли постоји одговарајући програм наставе за почетак учења страних језика од зачетка основног школовања и који је тачно узраст најприкладнији за започињање оваквог учења. Представљена је анализа модела наставе одабраних земаља света и оних на територији бивше републике Југославије. Главни део рада представља изучавање наставних планова и програма путем званичних докумената у оквиру језичке образовне политике Србије основног образовања. Као закључак рада истиче се да је потребно унапређивање наставе, али да је развој плана и програма на добром путу, док се за почетак учења страних језика период између првог и другог разреда основне школе може узети као најпогоднији. Даље истраживање могло би да укључи друге земље у којима је развијена вишејезичност. (примљено: 13. јануара 2021; прихваћено: 19. јуна 2021)
\end{abstract}

www.anali.fil.bg.ac.rs 


\section{1. Увод}

У Србији се поставља питање значаја учења страних језика у раном узрасту у формалном контексту када деца уче од првог или другог разреда основне школе један или два страна језика. У контексту школског система у Србији увиђају се могућности и потешкоће увођења учења више страних језика у раном узрасту, као и да су деца заинтересована да што више уче и проширују знање путем страних језика. Увидом у пример других земаља и каква је ситуација у Србији по питању учења страних језика, могуће је извести претпоставке о најпогоднијем периоду за почетак учења страних језика у школама. Теоријску подлогу рада чине истраживања из земаља са комплексним лингвистичким рељефом, тј. у којима је у оквиру система образовања присутна вишејезичност. Истраживање у овом раду је спроведено путем студије случаја, а предмет анализе су били наставни планови и програми почетних разреда основних школа у Србији и региону. У оквиру анализе обухваћене су методе, планови, теме итд. које би требало да буду обрађене у почетном периоду образовања везано за први, други и наредни страни језик. Сви планови и програми представљају званична документа Министарства образовања, односно у Србији Министарства просвете, науке и технолошког развоја.

Самим тим, у раду се приказује како функционише учење страних језика у раном узрасту у формалном контексту у одабраним земљама као што су Сједињене Америчке Државе, Канада и земље Европске Уније, а како у региону. Анализом тренутне ситуације у Европи и региону, путем наставних планова $и$ начина приступа настави, могу се препознати добри модели који би уз одговарајуће модификације могли да се доведу у везу и са српском језичком политиком. Поставља се питање колико су били успешни и које могућности постоје за увођења учења више страних језика од првог разреда основне школе као наставног предмета. Представља се и наставни план у првом циклусу основног образовања и васпитања у Србији, од првог до четвртог разреда основне школе, и наставни програм који се јавља у оквиру оваквог вида учења. Питања за анализу модела, планова и програма огледају се у томе да ли постоји одговарајући програм наставе за почетак учења страних језика од зачетка основног школовања и који је тачно узраст најприкладнији за започињање учења више страних језика, уколико се то може закључити из овог испитивања. Како би се јасно видело колики је помак у образовању и учењу страних језика у раном узрасту већ направљен, као и шта треба унапредити и истражити, приказани су модели наставе одабраних земаља у свету и региону.

\section{2. Формална настава страних језика на раном узрасту у свету}

Појава и коришћење више страних језика у образовању може се приписати одразу бројних фактора као што су језичка хетерогеност једне земље или регије, као у Луксембургу или Сингапуру, специфични друштвени или верски ставови и убеђења, жеља за промоцијом националног идентитета у Индији, Нигерији, на Филипинима итд. (Tucker, 1998: 4). Ипак, за почетак се у земљама које су при- 
хватиле учење више језика у раном узрасту, усвојио закон, где су се према Окал (Okal, 2014) у Сједињеним Америчким Државама и Канади, уз енглески као званичан језик, прихватили шпански, односно француски, јер су то језици који се подједнако уче као енглески. У Калифорнији, у Сједињеним Америчким Државама, усвојен је закон који отвара пут ка вишејезичности и мултикултурности. Он омогућава деци која не говоре енглески језик да се интегришу у друштво без високог знања тог језика. Слични случајеви јављају се у другим крајевима Америке, као и у Уједињеном Краљевству, на Филипинима и у Шведској (2014: 227).

Тако се, према Каминсу (Cummins, 2005), када се ради о наставним језицима у Сједињеним Америчким Државама, јављају преференције у одабиру језика и долази до губитка језика који нису довољно заступљени у раном школовању и настави јер нису били спроведени двојезични или вишејезични програми. У предшколском образовању врло брзо се међу децом прави разлика код домаћих и страних језика при учењу. Уз интеракцију са наставницима ојачавају се разлике међу овим језицима, а уколико није подржан страни језик у довољној мери, временом може доћи до његовог губитка (2005: 586). У складу са тим, према Нунан и Лам (Nunan/Lam, 1998: 124), како у Америци, тако и у Канади постоје различити језички програми, као на пример:

а) за очување језика: језици који нису доминантни се користе као средство за учење, а доминантан језик се предаје само као наставни предмет. Фокус је не само на другом језику, већ и на језику окружења;

б) заштићени језички програми: језици који нису доминантни пролазе кроз читав образовни процес и иду све до универзитетског образовања, а учење доминантног језика није обавезно;

в) канадско урањање: говорници доминантног језика су у пољу језика који није доминантан у оквиру пројекта урањања, те онда могу лакше научити одређени језик (енглески и француски где француски није етнички језик за енглеске говорнике, али ипак потпомаже промовисању тог језика);

г) програми за излагање језика: и доминантни језици и они који то нису користе се као средство за учење различитих предмета како би ученици добили могућност за коришћење више језика (1998: 125).

Слично томе, према истраживању Завишин (2017), током седамдесетих и осамдесетих година двадесетог века у Евроги се у све више школа уводи настава на два језика, на матерњем и страном, у складу са правом на билингвално образовање. Главни разлог томе је у неким случајевима била тежња за очувањем мањинских језика којима прети опасност од нестајања због њиховог недовољног присуства у систему образовања, или чак потпуног одсуства. Европска комисија је била главни покретач у развијању и очувању вишејезичне и вишекултурне свести, те се од земаља чланица Европске Уније захтевало да очувају мањинске језике који постоје на њиховим територијама. Стога један од европских постулата јесте да сваки грађанин европске заједнице говори барем три језика, од којих је један матерњи (Zavišin, 2017: 165-166). Потребно је узети у обзир тренутно стање у Европи по питању миграционе политике, где се добија 
слика мултикултурализма који из дана у дан све више доноси промене у оквиру стандардног приступа настави и учењу страних језика.

Рано учење више страних језика и прихватање различитих култура постало је својствено за земље у којима се јавља разноликост народа где се ствара потреба за коришћењем других језика који нису доминантни. У Ирској је, на пример, спроведен систем наставе где се јављају видови учења који олакшавају пружање подршке на енглеском језику за оне којима је тај језик додатни, други или трећи, језик, како истиче Кирван (Kirvan, 2016). Фокусирањем искључиво на комуникативне потребе ученика у основном наставном систему и програму, обраћа се пажња на минималну стручност ученика потребну за потпуно учешће у редовном образовању. Поред тога што је подршка развојна и педагошка, она представља и корисно средство за процену напретка учења језика ученика. Овакво учење подељено је на рецептивне (слушање и читање) и продуктивне вештине говора (интеракција, продукција и писање). Оне су представљене кроз три нивоа комуникативног језика - A1: пробој; A2: пут; A3: праг. Базиране су на нивоима Заједничког европског референтног оквира за живе језике (2001) и на језичким захтевима наставног плана и програма основних школа. Путем њих дефинише се шта ученик треба да ради у погледу граматичке и фонолошке тачности, контроле вокабулара и познавања правописа. Слична организација елемената језичких наставних планова јавља се у Шкотској и Велсу где се примењује интегрисани приступ настави и учењу језика. Структура начина рада која се фокусира на ученике омогућава личну евалуацију и праћење напретка по сопственој жељи и динамици кроз различите фазе личног развоја језичких знања (2016: 5). На тај начин испуњавају се циљеви који представљају успешно сналажење при активностима слушања, говора, читања и писања на више језика.

У Холандији, према Нап-Колоф (Nap-Kolhoff, 2010), крајем деведесетих година међу скоро сто хиљада деце у основним школама спроведена је анкета која је показала да тридесет и два процента деце поред холандског говори један или више језика у оквиру своје куће. Догађа се да у већим градовима има више деце која одрастају уз барем још један језик него оних који користе само национални језик у свом дому (2010: 17). Ово представља добар основ за развитак одређених језичких група и проширивање културних баријера, као и за даљи развој вишејезичног образовног система. Зато, према Хофман (Hoffmann, 1998: 149), у Луксембургу, већ у вртићу, односно обавезном предшколском образовању које се започиње са четири године, деца имају могућност да чују француски и португалски језик. Ово се догађа јер постоји велики број стране деце која на овим језицима међусобно комуницира. За њих је у том периоду битно да науче луксембуршки језик како би се лакше сналазили у школи што се, између осталог, постиже кроз интеракцију вршњака. Занимљиво је да је у Луксембургу већина становника по рођењу монолингвална где путем школског образовања они постају трилингвални јер у току образовања имају довољно интензивну наставу страних језика да се немачки и француски могу сматрати помоћним матерњим језицима. Сваки од језика има одређену улогу и функцију 
док се у току основног и средњег образовања прелази са луксембуршког, преко немачког, на француски језик. Заправо се луксембуршки језик користи на свим нивоима образовања при комуникацији када говорници имају потешкоћа у коришћењу друга два језика (1998: 150). Овде се јасно види да је потребно прилагодити образовни систем учењу страних језика у раном узрасту да се науче језици у оквиру формалног контекста, али и на нивоу друштвене заједнице.

Према томе, ако постоје потешкоће при учењу или коришћењу страних језика у оквиру учионице или ван ње, у Ирској се, према Кирван, у курикулуму обраћа пажња на три ставке које су: да је дете активан учесник у свом учењу; да постојеће знање и искуство детета представљају основу за учење; $и$ да у процесу учења треба да постоји учење уз сарадњу. Тиме се променио став учионице широм ове земље. Услед разноликости језика и култура које се налазе у оквиру школског становништва, створила се потреба за имплементацијом више језика у друштво (Kirvan, 2016: 4). Јавља се процена приступа настави и учењу страних језика у раном узрасту како би се то знање применило не само у школи него и у оквиру заједнице.

Тако у Луксембургу, према Хофман, већ у првој години основног образовања немачки језик постоји као наставни предмет. Немачки се учи од шесте године живота, интензивно, осам до девет часова недељно прве две године. Након тога прелази на пет часова до шестог разреда основне школе при узрасту од дванаест година када се готово губи. Луксембуршки се учи само једанпут недељно. Француски језик се уводи као наставни предмет у другој половини другог разреда основне школе, тј. почиње се са учењем у седмој години живота темпом од три сата недељно. Током наредне три године фонд часова француског се повећава на седам часова недељно. Према томе, француски језик у наставном плану заузима већи број часова у односу на луксембуршки и немачки језик. Ипак, они остају истакнути у свакодневном животу ученика јер их користе као језике за усмену комуникацију у школи и у спољној интеракцији. Циљеви ове наставе стављају акценат на стицање и усавршавање граматике, правописа $и$ усменог изражавања ових језика. Касније се очекује, у средњошколском образовању, да се више времена посвети развоју аналитичких вештина и проучавању књижевности (Hoffman, 1998: 151).

Дакле, као закључак луксембуршког модела, издваја се подршка државе где је образовни систем усмерен на читаву школску популацију, а не на одређене групе. Ово се неретко догађа у двојезичном образовању, иако у Луксембургу, осим миграната, не постоје језичке мањине. Луксембуршки систем има за циљ постизање потпуне билингвалности што се тиче немачког и француског језика. Оба језика користе се у институцијама и медијима у земљи, као и у формалним и неформалним интеракцијама. Са друге стране, луксембуршки језик представља национални сегмент земље и њене популације те није угрожен од стране друга два језика (Hofmann, 1998: 159). Као резултат ове мере у Луксембургу постоји развијена трилингвалност код ученика.

Тако Ескобар и Унамуно (Escobar/Unamuno, 2008: 23) објашњавају да се у шпанској регији Каталонији јавио сложен лингвистички сценарио као последи- 
ца глобализације и страха од губитка одређених језика. С једне стране, друштво захтева од образовних институција да подигну стандарде образовања увођењем школства на међународним језицима који су довели до:

а) спуштања границе обавезне полазне тачке за учење страних језика са шестог разреда (узраст дванаест година) на трећи разред основне школе (узраст осам година), док је недавно померено на први разред где деца већ са шест година имају могућност да уче стране језике;

б) повећања CLIL (Content and Language Integrated Learning) наставе и курсева који је подржавају у основним и средњим школама. С друге стране, константан прилив све већег броја миграната из целог света у Европу такође је приметан у Каталонији. Тиме се развијају нови језици и културе, те школе нису само двојезичне или тројезичне већ вишејезичне, као и мултикултуралне. Тако се јавља ново уређење, које се надовезује на претходне две ставке, од стране власти са три главна циља: процес нормализације у Каталонији; побољшање у односу напуштања школа и језичких компетенција на страним језицима који се предају у школама; и задовољење језичких потреба деце имиграната како би се омогућила њихова прогресивна интеграција у редовно образовање (2008: 24).

На сличан начин се у северној регији Шпаније, у Баскији, поред два званична језика, баскијског и шпанског, уводе страни језици као део обавезног образовања у овој аутономној покрајни. Према Сенос (Cenoz, 1998), до осамдесетих година најчешћи страни језик који се учио у шпанским школама био је француски, али је почетком двадесетог века дошло до преласка на енглески готово у потпуности. Ипак, знање енглеског језика у току и након школовања у већини случајева не показује завидне резултате. То се може приписати бројним факторима. Неки од њих су немогућност коришћења страног језика у заједници (аудио-визуелни материјал није био доступан осим на шпанском, на пример синхронизовани филмови) и недовољна мотивација за учење страног језика услед распрострањености шпанског по свету, где постоји иницијатива да се деца усмере на вишејезичност путем гостовања иностраних професора уз интерактивну наставу (1998: 180). Увођење додатних метода и материјала при учењу би можда допринело бољем прихватању језика који није у непосредном окружењу.

Тако је у Каталонији, у Шпанији, усвојен закон где је каталонски признат као мањински језик и постоји потреба да се учи у школи. Према Ескобар и Унамуно, одрађене су студије које имају за циљ да увиде обрасце употребе овог језика у школи и заједници. Такође, урађене су студије могућих последица на децу која говоре шпански и њихов прелазак са једног језика на други. Закључено је да не долази до битних разлика у погледу школског успеха између деце која говоре каталонски или шпански језик. Дакле, обраћа се пажња на приступ учењу више страних језика, поред мањинског, и издвајају се три вида:

а) подржавање нових учесника у процесу учења два званична језика - то подразумева гарантовано обогаћивање образовног искуства према каталонском као језику који може бити потиснут шпанским и самим тим имати ограничен приступ; 
б) обезбеђивање мера које гарантују да сви ученици до краја свог образовања имају добро познавање барем два језика за међународну употребу без обзира на њихово језичко порекло;

в) успостављање оквира за иницијативе које ће довести до увећања броја ученика, прихватања и промоције језика које доносе имигрантске породице (Escobar/Unamuno, 2008: 6, 24). Овим путем се обраћа пажња на значај учења више језика у оквиру раног узраста и имплементације језика у друштво. Исто тако, узима се у обзир могућност да дете можда неће у потпуности савладати све три језичке баријере, али ће имати основ за напредак у културном и друштвеном учењу путем одређеног познавања више страних језика и култура.

У Баскији, пак, како истиче Сенос, постоје три модела учења страних језика које родитељи могу да одаберу за своје дете, који сматрају најприкладнијим: модел А, Б и Д (у баскијском не постоји слово Ц). Модел А намењен је изворним говорницима шпанског језика који се одлуче за шпански као први, а баскијски као други језик. Уче га [баскијски] четири до пет сати недељно до нивоа минималног познавања језика. Модел Б представља могућност да изворни говорници шпанског језика науче баскијски као матерњи и постану билингвални говорници. Оба језика се користе подједнако у току наставе иако постоје варијације од школе до школе. Овај модел сличан је раније поменутом канадском програму урањања. Последњи модел Д узима баскијски као језик наставе, док се шпански предаје четири до пет сати недељно. Овим моделом се највише подржава очување баскијског језика (Cenoz, 1998: 177). На све ове моделе се укључује одређени страни језик као додатни предмет.

Самим тим, у шпанским регијама где имамо два званична језика, постоји велика могућност да деца постану трилингвална. Према реформама из 2002/2003. године, како истиче Фернандес-Уљоа (Fernández-Ulloa, 2005) у Баскији постоји и модел $X$ који подразумева да се не учи баскијски језик, али родитељи ретко кад бирају овај модел за своју децу. Ипак, баскијски се говори у кућама родитеља који су учили овај језик при свом школовању у оквиру модела Д те и на тај начин преносе језик на децу. Друштвени притисак, одсуство модела А у одређеним областима, пролазна мода и слично, утичу позитивно на ученике да упишу модел Б или Д (2005: 726). Тако је све чешћа настава на шпанском и баскијском, уз то да има све више квалификованих професора.

Примери праксе у европским земљама од великог су значаја, као и примери из региона јер се услед географске и друштвено-културне блискости народа могу извући одређене паралеле у учењу и настави. Увидом у примере добре праксе вишејезичног учења у образовним системима земаља махом у Европи, може се увидети сличност са системом који постоји у неким земљама у региону представљених у наредном одељку.

\section{3. Формална настава страних језика на раном узрасту у региону}

Примери добре праксе могу се извући како из горепоменутих тако и из образовних система земаља насталих на територији бивше Југославије. У Ре- 
публици Српској, која припада Федерацији Босне и Херцеговине, према Наставном плану и програму за основно образовање и васпитање (2014), предвиђено је учење два страна језика и српског, као матерњег. Међутим, постоји случај мањинских језика и школа где се настава одвија на српском, али имају додатну наставу на једном од језика народа. С обзиром на то да је у питању деветогодишње основно образовање, ученици крећу већ са шест година у школу. Први разред представља неку врсту прелаза између предшколског и школског образовања. Самим тим, у првом разреду не постоји предмет као што је српски језик или неки страни језик, већ само говор и изражавање. Тим путем би деца требало да се припреме за учење српског и других језика. У другом разреду ученици почињу са школским радом уз предмете као што су српски језик, али и језик националних мањина. Учење првог страног језика ученици започињу тек у трећем разреду, а учење другог страног језика, још касније, у шестом разреду основне школе. На тај начин први страни језик, где је енглески у питању, учи се седам година и предвиђено је да се дође до нивоа А2 што представља коришћење и разумевање изолованих реченица, једноставну и непосредну комуникацију, статус образовања ученика и слично. За други страни језик, где је могућ избор између немачког и руског, ученик достиже ниво А1 што представља најосновнији ниво знања (Републички педагошки завод Републике Српске, 2014: 4, 44, 647).

Према томе, није могуће достићи исти ниво познавања првог и другог страног језика где би се могао извући закључак да је потребно кренути раније са учењем другог страног језика у складу са могућностима ученика и наставе. Треба нагласити да је од 2019. године у примени нови План и програм образовно-васпитног рада у првом разреду основне школе који се фокусира на уважавање индивидуалних разлика ученика (Републички педагошки завод Републике Српске, 2019: 3). У примени су и други нови наставни програми, али се у погледу учења страних језика не разликују у односу на раније споменути.

Према Предметнику основне школе (2014), тј. словеначком актуелном наставном плану и програму у основном деветогодишњем образовању ученик има могућност да учи словеначки језик од првог разреда. Од другог разреда основне школе има обавезан предмет страних језика. Може узети први страни језик још у првом разреду основне школе, али као изборни предмет. Други страни језик може да изабере у седмом разреду основног образовања као изборни предмет. Исто тако, ученик има могућност да у току основног школовања, уколико жели, изабере додатне часове језика како би унапредио знање другог страног језика, поредећи са првим страним (Урадни лист РС, 20/2014: 2).

Слично томе, у Црној Гори, према Решеюу о утврђиваюу општег дела јавно важећег образовног програма за основно образовање и васпитање (2017), добија се увид у програм где се страни језици уче као обавезни предмети, поред црногорског као матерњег. Први страни језик је енглески и учи се од првог разреда основне школе, два пута недељно, док се од петог разреда фонд часова повећава на три недељно. Други страни језик може да се изабере, али се учи као 
обавезан предмет. Ученик може да бира између руског, немачког, италијанског и француског језика и тај језик учи од шестог разреда, два пута недељно. Ипак, постоји и план наставе за установе у којима се настава одвија на албанском језику где се он похађа као матерњи језик, а црногорски као додатни језик уз фонд часова два пута недељно (Завод за школство, 2017: 3).

Занимљиво је да је и у црногорском плану наставе, као у словеначком и оном из Републике Српске, у питању деветогодишње основно школовање. Исто тако, у Македонији, према Решение за утврдуваюе на Наставен план и наставни програми за воспитно-образовната дејност во основно училиште во кеошто се реализира Меѓународна програма за основно образование (2016), у питању је деветогодишње основно образовање, али се дели на три образовна периода: од првог до трећег, од четвртог до шестог и од седмог до деветог разреда. Поред македонског као матерњег језика, од првог разреда основног образовања изучава се и енглески језик као обавезни предмет. Уколико постоје припадници друге заједнице, они похађају наставу на језику и писму дотичне заједнице, као на пример на албанском, турском, српском или босанском језику, док наставу македонског језика имају од четвртог разреда. Ипак, уз македонски језик учи се ћирилично писмо, док је за стране језике потребно научити и латинично. Што се тиче првог страног језика, учи се два пута недељно у првом и другом разреду, а од трећег до краја основног школовања постоји фонд од три часа недељно. Други страни језик учи се, као и у случају црногорског образовног система, од шестог разреда два пута недељно (Службени весник на Република Македонија, 127/2016: 4).

Међутим, у Хрватској, долази до другачије структуре услед необавезног учења другог страног језика у раном узрасту, како истичу Кошута, Патекар и Вичевић Ивановић (2016). Ово у великој мери онемогућава спровођење барем једног од раније поменутих европских модела учења више страних језика $и$ интеграције вишејезичности у образовне институције. Постоји увек могућност да се прида више значаја изборним предметима и страним језицима током примарног образовања, али и да се узме у обзир улога плурилингвизма у раном учењу страних језика поредећи са другим земљама. Иако је постојала иницијатива да се уведе вишејезичност у хрватски језички образовни систем, превагнула је доминација енглеског и ставила у сенку друге језике (Košuta, Patekar i Vičević Ivanović, 2016: 12). Према хрватском Наставном плану и програму за основну школу (2005) који је актуелан и данас, а примењује се од школске 2006/2007. године, укључује се први страни језик од почетка школовања, тј. од првог разреда основне школе. Други страни језик могуће је узети у четвртом разреду основне школе и то као изборни предмет. Ученици могу да изаберу страни језик поред понуђених осталих предмета. Ово не значи да је обавезно учење страног језика као наставног предмета већ да имају могућност избора између више предмета и страног језика уколико имају жељу да га уче. Уколико изаберу страни језик као свој изборни предмет у обавези су да тај предмет похађају убудуће те им на одређени начин постаје обавезан. Након што су га 
изабрали, обавезују се да га уче до краја основног школовања. На овај начин у току основне школе први страни језик ученици могу научити до нивоа А2 што је већ напоменуто колико знање имају. Други страни језик могу похађати до нивоа A1+ што је ниво између A1 и А2 и подразумева способност комуницирања у оквиру познатих тема, разговор о свакодневним ситуацијама, врло једноставно описивање итд. (Народне новине, 76/2005: 130-131).

Оно што је занимљиво јесте да први страни језик не мора бити енглески. Како кажу Кошута, Патекар и Вичевић Ивановић, ученици имају прилику да бирају између немачког, француског, италијанског и енглеског језика. Исто важи и за други страни језик где могу да изаберу неки од ова четири језика искључујући онај који су учили од првог разреда. Међутим, иако постоје предлози курикулума страних језика као што су енглески, немачки, италијански и француски језик, где се учење започиње у првом разреду основне школе потребно је усвојити те промене. Поврх свега, у Хрватској се поставља питање да ли су наставници довољно обучени за извођење наставе страних језика у оквиру прве четири године основне школе, јер се јавља занемаривање раног учења језика и наставе у оквиру образовања наставника на универзитетском нивоу (Košuta, Patekar i Vičević Ivanović, 2016: 12). При обуци наставника за будуће просветне раднике, фокус се не ставља на њихово оспособљавање за држање наставе деци у оквиру раног узраста. Припрема за наставу и образовање наставног кадра прилагођава се часовима од четвртог или петог разреда основне школе, односно узрасту деце од десет, а не шест или седам година.

Самим тим, иако је српски образовни систем што се тиче година трајања основног образовања, близак хрватском, по погледу раног учења и отворености за могућности имплементације више језика, ближи је осталим земљама региона. Паралела у учењу може се повући у односу на мањинске језике, али и на учење страних језика у раном узрасту у оквиру формалног образовања, као што ће се видети у наставку.

\section{4. Формална настава страних језика на раном узрасту у Србији}

Главно питање у раду је везано за узраст у којем је најпогодније започети учење страног језика. Када се погледају историјске чињенице, према Поткоњаку (1977), види се да је прва промена настала у Југославији, према томе и у Србији, 1958. године. Тада је донет Опити закон о школству и усвојена је основна осмогодишња школа као јединствена школска институција за целу земљу. Ова одлука се веома разликује од претходне структуре образовања која је представљала четворогодишње основно школовање, а страни језици су се у том случају учили тек у каснијим разредима (Potkonjak, 1977: 41). Уколико су ученици настављали школовање у нижу гимназију, имали су прилику да уче страни језик.

Тако су се, према Ђурић (2016), у оквиру новог закона јавили предлози за увођење учења страних језика од трећег разреда, али је оглед ипак спроведен на четврти разред основног школовања. С тим у вези је у Новом Саду, године 1957/1958. започет оглед учења страног језика, француског и немачког, по ау- 
дио-лингвалној методи, тј. без читања и писања, већ само уз слушање, гледање аудио-визуелних материјала и причање. Позитивна искуства овог огледа забележена су у оквиру документа о основној школи Савезног завода за проучавање иколских и просветних питања (Đurić, 2016: 135-136). Остала истраживања и испитивања су приказала велику заинтересованост за учењем страних језика од почетка образовања, како истиче Жиропађа (2007). Касније се јавио и захтев родитеља за увођење наставе страног језика од првог разреда основне школе. Они су сматрали да доприноси знању и разумевању других култура, као и могућности да се лакше научи страни језик (Žiropađa, 2007: 129). На тај начин ставља се акценат на језик и придаје му се заслужена важност у развоју детета.

Самим тим, након шездесетих година двадесетог века уведен је систем учења првог страног језика од трећег разреда основне школе, а другог страног језика од петог разреда и овакав систем није се мењао до 2002/2003. године када је покренута нова реформа образовања. Према европској имплементацији вишејезичности и интеркултурности, у оквиру анализе коју је обавила Ђурић, прихваћен је предлог Комисије за развој иколског програма да се учење страног језика у школи започне кад и учење матерњег. Потребно је да се учи од првог разреда основне уз математику и српски као језик који није матерњи и то до краја основног и средњег образовања. На овај начин, подразумевало се, према Савету Европе (2001), да се уведе рано учење страног језика, да два страна језика буду обавезна при образовању и да се обезбеди учење по различитим моделима: кроз двојезичну, интензивну, факултативну, блок наставу и слично (2016: 546).

Захваљујући горепоменутим реформама, у Београду у септембру 2004. године почело је учење српског и француског језика, као страног, у основној школи „Владислав Рибникар” у оквиру дуалне наставе и образовања. Већ наредних година, према Ђурић (2014), шири се двојезична настава углавном у Београду, али се временом јавља и у другим градовима у Србији. Постоји настава на српском и неком од страних језика као што су француски, енглески, руски и немачки језик, а у основној школи у Суботици покренута је настава и на мађарском језику. Такође, у преко тридесет школа уведена је факултативна настава кинеског језика (2014: 97). Као што се на примеру наведених језика може видети, више се не говори о двојезичности него о вишејезичности која се постепено укључује од раног узраста. С тим у вези, потребно је обратити пажњу на садашњи наставни план и програм првог циклуса образовања, односно од првог до четвртог разреда основне школе. Тиме ће се добити јаснија слика формирања раног учења страних језика у оквиру основног образовања у Србији двадесет првог века.

\section{1. Наставни план и програм страних језика на раном узрасту у Србији}

Прилагођавањем образовног система потребно је размишљати о деци и њиховом прихватању односа језичког програма и учења страних језика у раном узрасту. Ако се има у виду да је деци потребно да учење буде занимљиво, битно је да садржи нешто ново, како би било изазовно, али и део познатих ствари, како 
се дете не би обесхрабрило (Vygotsky, 1978: 86). Самим тим, када није у питању билингвална настава, учење првог страног језика започињало се од трећег разреда основне школе, а други од петог, уколико није другачије одлучено у оквиру одређене школе. Ипак, према Правилнику о наставном плану за први, други, трећи и четврти разред основног образовања и васпитањь и наставном програму за трећи разред основног образовања и васпитања (2018), страни језик се учи од првог разреда основне школе као обавезан предмет. У оквиру овог плана предвиђено је да у прва четири разреда недељни број часова за страни језик буде два часа. Увођење учења страног језика од првог разреда основне школе, према овом правилнику започето је од школске 2018/2019. године (Службени гласник 12/2018: 2).

Зато су, према Наставном плану за трећи разред основног образована и васпитана (2018), предвиђена два програма. У оквиру првог програма представљен је план учења првог страног језика од трећег разреда, док други план подразумева учење првог страног језика од првог разреда основне школе. Уколико се страни језик учи од првог разреда основне школе или од трећег, циљ наставе у раном узрасту представља оспособљавање ученика да комуницира на основном нивоу у усменом и писменом облику о свакодневним темама и о оним из непосредног окружења. У оба случаја предвиђено је да кроз наставу страних језика ученик обогати сопствено знање матерњег језика и културе уз контакт са другим језицима и различитим културама. Ту се код ученика развија радозналост, истраживачки дух и отвореност према комуникацији на другим језицима са говорницима истих страних језика (Службени гласник 12/2018: 33).

Такође, према Правилнику о наставном програму за четврти разред основног образовања и васпитања (2018), програм предвиђен за четврти разред подразумева приближно исте тематске целине које је потребно прећи било да се ради о четвртој години учења страног језика или о другој. Ипак, како овај разред представља прилагођавање $и$ уклапање обе групе ученика, и један $и$ други програм су усмерени на развијање вештина разумевања. Дакле, у трећем разреду ствара се тенденција да се усагласе програми оних који су већ две године учили страни језик и оних који тек почињу да га уче. Тако да се, као што је већ споменуто, оба наставна предмета фокусирају на четири језичке вештине: говор, разумевање, читање и писање. У складу са узрастом и карактеристикама ученика очекује се да у четвртом разреду, уз можда неколико допунских часова, могу достићи приближно исти ниво компетенција они који су учили страни језик три године и они који су тек на другој години учења тог језика (Службени гласник 12/2018: 48).

Како ученик напредује из разреда у разред тако стиче сигурност и знање у његовој употреби, те ће касније у трећем и четвртом разреду користити незнатно сложеније конструкције. Према Наставном програму за трећи разред основног образовања и васпитања (2018), ако се ради о трећој години учења страног језика у трећем разреду предвићено је да се утврди претходно стечено знање. Уколико је почетак учења језика био у првом разреду, потребно је да се ученици 
уведу у вештину разумевања писаног текста и писања садржаја које су раније научили како би се даље развијала комуникативна настава. Тако је предвиђен сличан приступ настави било да се ради о ученицима који настављају страни језик трећу годину за редом или о онима који тек почињу са учењем страног језика у трећем разреду. Главна одлика наставе јесте да је комуникативна, тј. да таква настава сматра језик средством комуникације. Овакав приступ настави страних језика, када се ради о учењу страног језика од првог разреда основне школе, заснива се на примени одређених ставова:

- да су теме које се обрађују у пољу интересовања ученика;

- да ученици у почетку треба да слушају, а касније полако да говоре на страном језику, као и да је тада битна језичка порука, а не потпуна граматичка прецизност;

- да говор наставника мора бити прилагођен узрасту и знању ученика, а изворни говорник не може бити узор због релативних критеријума тачности;

- да се настава заснива на социјалној интеракцији како би се унапредио квалитет и квантитет језичког материјала: рад у учионици се окреће потрази за информацијама, решавању проблема и задацима који имају јасан циљ (Службени гласник 12/2018: 34).

У истом правилнику од трећег разреда додата је ставка која се односи на језичку грађу која треба да буде кумулативна и да се надовезује на већ обрађено градиво.

Према томе, што се тиче наставног програма, у оквиру Правилника о наставном плану за први ииклус основног образовања и васпитања и наставном програму за први разред основног образовања и васпитања (2018) предвиђено је да се у првом разреду започне учење једног од следећих језика: енглеског, немачког, француског, италијанског или шпанског. С обзиром да је у питању рани узраст потребно је прилагодити наставу и узети у обзир различите стилове учења. Тако постоји могућност укључивања одређених врста наставе, као што cy:

- визуелна наставна средства: картице, постери који помажу при увођењу вокабулара, где се вежба уз хорско понављање и избегава осећај несигурности;

- пантомима: као врста драмске технике и потпуног физичког контакта, а вежбају се именице, глаголи, придеви и говорне ситуације - развија се машта и креативност;

- одговарајући контекст: приче, слике, песме итд. како би се научила посебна лексика;

- дијалошки модели: основа за „имитирање”, за развијање говора на страном језику;

- пројектне активности: рад у пару или групи ради олакшања задатка и дружења;

- драмске активности: језик у одговарајућем контексту, различити углови гледања; 
-читање и писање и граматички садржаји, али као необавезне активности у првом и другом разреду због латиничног писма и касније обраде граматике (Службени гласник 15/2018: 30).

На тај начин, треба имати у виду циљ у оквиру учења страних језика, према Наставном програму за трећи разред основног образовања и васпитања и Правилнику о наставном програму за четврти разред основног образовања и васпитања. Тај циљ јесте да се путем наставе страног језика на раном узрасту у формалном образовању ученик заправо оспособи да комуницира на основном нивоу у усменом и писменом облику о темама које чине његово непосредно окружење. Поред тога, настава страног језика треба да подстакне развијање свести о сопственом напредовању у погледу мотивације за учење језика и већ поменутог приближавања другим културама, традицијама и њиховог разумевања. Она треба да подстакне машту, креативност, радозналост, као и употребу страних језика у личне сврхе, тј. у свакодневној комуникацији и из личног задовољства (Службени гласник 12/2018). Када се ово узме у обзир, увиђа се потреба за стварањем приступа настави која може те ставке омогућити.

Дакле, према Наставном програму за трећи разред основног образовања и васпитања, комуникативно-интерактиван приступ наставе страних језика укључује одређене ставке које имају за циљ да олакшају учење и начине га занимљивијим. Самим тим, садржи: обраду језичког садржаја кроз социјалну интеракцију која је пажљиво осмишљена уз јасне инструкције и ученици се сматрају одговорним и активним учесницима; наставни програм који треба да је схваћен као динамичан, прилагођен и заједнички припремљен уз активности и задатке у оквиру поља интересовања ученика, а где се учионица прилагођава настави сваког дана; и наставник треба да је посредник у учењу које омогућава приступ и прихватање нових идеја (Службени гласник 12/2018: 40). У овом правилнику за учење страног језика од трећег разреда постоји још једна ставка која се односи на рад на пројектима као активности која подстиче ученике да се баве истраживачким радом и да то повезују са другим предметима. Исто тако, узимају се у обзир и врсте активности које се спроводе, а да су прилагођене нивоу знања и интересовања ученика. Уколико се ове активности комбинују, допуњују и примењују сваки пут на другачији начин, одржаће наставу језика динамичном и учиниће да се ученици осећају пријатно и задовољно при учењу страних језика. Тако су представљене следеће технике:

- слушање: наставника, аудио записа везаних за физичке активности, али и за рад у учионици, израда вежби према упутствима професора и слично; - рад у паровима или групама: дијалози, игре уз улоге, певање у групи;

- мануелне активности: прављење игара, постера, заједничких материјала и друго;

- упоређивање: погађање, цртање по диктату, имитирање исказа гестом и обрнуто;

- решавање проблема у разреду: договори и пројекти; 
- разумевање писаног текста: повезивање слова и гласова, речи и слике, одговарање на једноставна питања у вези с текстом, извршавање прочитаних упутстава;

- писмено изражавање: повезивање гласова и слова, приказивање и повезивање речи и реченица са цртежом или сликом, проналажење речи која недостаје итд. (Службени гласник 12/2018: 41).

Слично томе, теме које се обрађују приликом почетка учења страног језика су углавном оне које су познате ученицима, односно ситуације и догађаји у њиховом непосредном окружењу. Према томе, што се тиче тематских јединица и наставног програма, у оквиру Правилника о наставном плану за први ииклус основног образовања и васпитань и наставном програму за први разред основног образовања и васпитања након завршеног првог разреда и прве године учења одређеног страног језика подразумева се да ученик уме да примењује најједноставнија језичка средства. То значи да уме да: поздрави и отпоздрави, представи себе и другог, разуме јасно постављена питања личне природе, упутства, молбе, честитке, да одговори на њих и упути исте. Такође, треба да разуме позив, реагује на њега и да га упути, да искаже захвалност, извињење и прихвати их, да препозна и опише бића и места из непосредног окружења и где се налазе у простору, као и да разуме, изрази и реагује на свакодневне исказе у вези основних потреба. Требало би да зна и да искористи и препозна исказе за допадање нечега и обрнуто (Службени гласник 15/2018: 32). Ове теме потребно је да ученик буде у стању да изрази једноставним језичким средствима у складу са узрастом и дужином учења страног језика. Теме које се обрађују током прва четири разреда основне школе јесу исте за сва четири разреда, али се разликују по интензитету њиховог изучавања у складу са узрастом ученика и нивоом знања.

Према Наставном програму за трећи разред основног образована и васпитања постоје издвојене теме и ситуације које се обрађују када је у питању трећа година учења страног језика и када је у питању прва. На тај начин, неке теме као што су школа, школски прибор, активности, празници и исхрана остају исте за обе године учења. Међутим, друге теме се разликују по продубљивању одређених садржаја, вокабулара, ситуација које су на сложенијем нивоу у трећој години учења. Када се у првој години учења страног језика у трећем разреду учи тема: ја и моји другови - обрађује се појам другова и особа из непосредног окружења уз неке игре према годишњим добима, док се у трећој години обрађује дружење и спорт у ширем оквиру. Исто то се догађа када се говори о темама: породица и блиско окружење; мој дом; одећа; окружење и друге ситуације са темама које се разликују у трећој години учења као додатне теме (Службени гласник 12/2018: 34). Самим тим, долази до покушаја усклађивања тематских садржаја у погледу ових различитих година учења.

На тај начин, према Правилнику о наставном програму за четврти разред основног образовања и васпитања обрађују се исте тематске целине као и у претходном разреду само на вишем нивоу, обнављањем већ пређеног градива 
и изучавањем нових проширених тема и ситуација. Уз покривање истоветних тема које су обрађене у претходном разреду требало би, као што је већ наглашено, на крају четвртог разреда да и једни и други ученици достигну једнак ниво знања према пређеном градиву (Службени гласник 12/2018). Ипак, као што је раније поменуто, учење страног језика највише захтева време и његово улагање, те је и пролазност времена веома битна, тј. чињеница да се стечено знање слободно користи и постепено примењује, а не убрзаном методом. Ово поготово не треба примењивати у раном узрасту где се, ако се учењу не приступи на одговарајући начин, јављају одређене препреке у виду анксиозности, губитка мотивације, страха од прављења грешака и слично.

Самим тим, предвиђено је, према Правилнику о наставном плану за други ииклус основног образовања и васпитања и наставном програму за пети разред основног образовања и васпитања (2018), да се почне са учењем другог страног језика као обавезним изборним предметом од петог разреда основне школе. Ученик има право да изабере страни језик са листе језика који су у понуди школе у складу са њиховим кадровским могућностима. Тај језик мора да изучава до краја другог циклуса основног школовања, тј. до краја основног образовања, два пута недељно. Дакле, постоји могућност да се бира у најчешћим случајевима између енглеског, уколико је неки други језик изучаван као први, немачког, француског, руског, италијанског и шпанског језика. Фонд часова је усклађен тако да ученици имају оба страна језика два пута недељно (Службени гласник 15/2018: 3). Када се има у виду претходна анализа учења првог страног језика и узимање другог у петом разреду, потребно је увидети колико постепено учење страног језика од првог разреда основног образовања доноси предности. То се може закључити погледом на убрзано учење од трећег разреда $и$ могућу конфузију при узимању другог страног језика за кратак период учења.

Међутим, иако се сматра да је рано детињство погодан период за почетак учења страних језика, поред неадекватних услова за рад, проблем представљају и превелика очекивања за учење страних језика у том периоду. Према Лончаревић и Суботић (2004), школе би требало да омогуће прикладне услове за спровођење наставе страних језика од првог разреда основне школе, као и усклађен наставни план и програм. Овде мора да постоји уједначеност између избора радног материјала, наставног програма, евалуације и метода рада. Да би вишејезична настава била успешна, потребно је увести више часова недељно, а краћих, у мањим групама и на прикладан начин узрасту којем се предаје (Lončarević i Subotić, 2004: 95). Према томе, у вишејезичном образовању треба прилагодити наставу како би узнапредовала у односу на традиционалан приступ. Према Вучо (2014), путем педагошких, психолошких и методичких средстава јавља се интерактивна настава, улога наставника који помаже ученику у подстицању како би напредовао. Присутна је и примена разних активности при држању наставе, као што су комуникативне вежбе, игре, садржаји који подижу свест о мултикултурности и слично (Vučo, 2014: 117).

Стога би требало прилагодити наставу и припремити дете на учење страних језика уз прелазак из система предшколског у школско образовање. Када 
се одговорност за наставне активности дели између наставника и ученика, резултат је углавном повећана заинтересованост ученика да буду активније укључени у процес учења језика и организовање наставе (Kirvan, 2016: 10). Тако се омогућава ученицима да буду део процеса оцењивања и могу да разумеју како им то може помоћи при учењу, као алат за евалуацију учења, а не да буде усмерен на контролу и учитељски резултат. Ту је, дакле, важна педагошка промена у образовању вишејезичног школовања где ће, када се користе монолингвалне стратегије образовања, мања бити успешност двојезичног или вишејезичног програма. Према Каминсу, треба применити вишејезичне стратегије које служе експлицитном укључивању страног језика у наставу, а не уз одвојени приступ. Потребно је прилагодити језички програм за увођење вишејезичне наставе, који се јавља и у случају монолингвалних програма. Неопходно је обратити пажњу на сродне односе међу језицима и на тај начин приступити учењу, како би се путем једног језика други брже и лакше научио. У том случају ученици из различитих језичких заједница могу да сарађују тако што користе два или више језика ради ефикаснијег учења (Cummins, 2005: 588). На тај начин, проналажење адекватног наставног плана и програма, али и наставног кадра, од велике је важности при учењу страних језика у раном узрасту. Увођење формалног учења више страних језика у образовне институције на почетку школовања може показати велике помаке, како за развој детета, тако и за задовољство учења језика на адекватан начин и у прикладном узрасту.

\section{5. Закључак}

Приказане су земље као што су Луксембург, Ирска, Шпанија и друге, које имају развијен систем школовања на незнатно другачији начин него у Србији и земље у региону где се истичу сличности и разлике учења страних језика. Такође, представљен је увид у тренутну ситуацију у школама у Србији, те какви су модели вишејезичности до сада уведени. Ипак, јављају се изазови у оквиру образовне политике, наставног кадра који одређени језик предаје, припрема и прилагођавања наставе за рани узраст и друго. Поред тога, учење страних језика у другим земљама приказује могуће начине учења више страних језика у раном узрасту у формалном контексту. Уз све информације и податке који се јављају може се извући закључак за могућност имплементирања примера наставних планова вишејезичног образовања других земаља у наставни план у Србији, а да су прилагођени за српски образовни систем. Слично томе, број часова и количину наставе које један ученик треба да савлада, потребно је прилагодити новом систему рада који се разликује од предшколског образовања. Према анализираним плановима и програмима може се закључити да би било пригодно увести додатне нове активности за децу у оквиру учења страних језика у другој половини првог разреда или у другом разреду у основном школовању у Србији. Тако се може запазити да би најлагоднији период за почетак дечијег учења више страних језика у раном узрасту у формалном контексту био заправо између првог и другог разреда основне школе. На тај начин, уз 
постепено приближавање нових култура, различитих језика и пригодне методе наставе, може се причати о успешном учењу страних језика на нивоу формалног образовања у оквиру раног узраста. Даље истраживање могло би да укључи друге земље у којима је развијена вишејезичност, а нису обрађене у оквиру овог рада због ограничења истраживања, као и могуће нове планове и програме већ анализираних земаља.

\section{Литература}

Вучо, J. (2014). Двојезична настава страних језика у Србији. У Ј. Филиповић и О. Дурбаба (ур.), Језици у образоваюу и језичке образовне политике (стр. 107-151). Београд: Филолошки факултет.

[Vučo, J. (2014). Dvojezična nastava stranih jezika u Srbiji. U J. Filipović i O. Durbaba (ur.), Jezici u obrazovanju i jezičke obrazovne politike (pp. 107-151). Beograd Filološki fakultet]

Ђурић, Љ. (2014). Вредновање раног школског учења страних језика у Србији: заглушујућа тишина. У Ј. Филиповић и О. Дурбаба (ур.), Језици у образовању и језичке образовне политике (стр. 77-106). Београд: Филолошки факултет.

[Đurić, Lj. (2014). Vrednovanje ranog školskog učenja stranih jezika u Srbiji: zaglušujuća tišina. U J. Filipović i O. Durbaba (ur.), Jezici u obrazovanju i jezičke obrazovne politike (pp. 77-106). Beograd: Filološki fakultet]

Ђурић, Љ. (2016). Страни језици у образовној политици Србије. Београд: Филолошки факултет Универзитета у Београду.

[Đurić, Lj. (2016). Strani jezici u obrazovnoj politici Srbije. Beograd: Filološki fakultet Univerziteta u Beogradu]

Лончаревић, М., Суботић, Љ. (2004). Прва искуства у настави страних језика у првом разреду основне школе у општини Сомбор. Норма, 10(1-2), 87-95.

[Lončarević, M., Subotić, Lj. (2004). Prva iskustva u nastavi stranih jezika u prvom razredu osnovne škole u opštini Sombor. Norma, 10(1-2), 87-95]

Cenoz, J. (1998). Multilingual Education in the Basque Country. In J. Cenoz \& F. Genesee (Eds.), Beyond Bilingualism: Multilingualism and Multilingual Education (pp. 143174). Clevedon: Multilingual Matters.

Zajednički evropski referentni okvir za žive jezike. (2001). Council of Europe. Common European Framework of Reference for Languages: Learning, teaching, assessment. Cambridge: Cambridge University Press.

Cummins, J. (2005). A proposal for Action: Strategies for Recognizing Heritage Language Competence as a Learning Resource within the Mainstream Classroom. The Modern Language Journal, 89(4), 585-592.

Escobar, C. U., Unamuno, V. (2008). Languages and language learning in Catalan Schools: From the bilingual to the multilingual challenge. In Ch. Hélot \& AnneMarie de Mejía (Eds.), Forging Multilingual Spaces (pp. 1-31). Barcelona: University of Barcelona. 
Fernández-Ulloa, T. (2005). La Educación Bilingüe en el País Vasco: Problemas y Retos. In J. Cohen, K. T. McAlister, K. Rolstad \& J. MacSwan (Eds.), Proceedings of the $4^{\text {th }}$ International Symposium on Bilingualism (pp. 703-729). Sommerville, MA: Cascadilla Press.

Hoffmann, Ch. (1998). Luxembourg and the European Schools. In J. Cenoz \& F. Genesee (Eds.), Beyond Bilingualism: Multilingualism and Multilingual Education (pp. 143174). Clevedon: Multilingual Matters.

Kirvan, D. (2016). Learning outcomes in plurilingual environments: reflections on curriculum, pedagogy and assessment. National Council for Curriculum and Assessment, 1-22.

Košuta, N., Patekar, J., Vičević Ivanović, S. (2016). Plurilingvism in Croatian foreign language policy. CLARC: Perspectives on Language Planning and Policy. Rijeka: University of Rijeka.

Nap-Kolhoff, E. M. (2010). Second language acquisition in early childhood: a longitudinal multiple case study of Turkish-Dutch children. Utrecht: LOT.

Nunan, D., Lam, A. (1998). Teacher Education for Multilingual Contexts: Models and Issues. In J. Cenoz \& F. Genesee (Eds.), Beyond Bilingualism: Multilingualism and Multilingual Education (pp. 117-140). Clevedon: Multilingual Matters.

Okal, B. O. (2014). Benefits of Multilingualism in Education. Universal Jornal of Educational Research, 2(3), 223-229.

Potkonjak, N. (1977). Od etatističke ka samoupravnoj socijalističkoj osnovnoj školi. Beograd: Institut za pedagoška istraživanja/Prosveta.

Tucker, R. G. (1998). A Global Perspective on Multilingualism and Multilingual Education. In J. Cenoz \& F. Genesee (Eds.), Beyond Bilingualism: Multilingualism and Multilingual Education (pp. 3-15). Clevedon: Multilingual Matters.

Vygotsky, L. (1978). Mind in Society: The Development of Higher Psychological Processes

(M. Cole, V. John-Steiner, S. Scribner \& E. Souberman, Eds.). London: Harvard University Press.

Zavišin, K. (2017). Nastava jezičkih i nejezičkih sadržaja na stranom jeziku - predlog modela kursa za usavršavanje nastavnika u CLIL kontekstu. Анали Филолошког факултета, 29(1), 165-181.

Žiropađa, Lj. (2007). Uzrast i učenje stranih jezika. Nastava i vaspitanje, 2, 119-130.

\section{Dunja D. Brankov}

Resumen

LA ENSEÑANZA DE LENGUAS EXTRANJERAS EN EDAD TEMPRANA: PRESENTACIÓN DE ENSEÑANZA DE MODELOS Y DE PLAN DE EDUCACIÓN DE SERBIA

El grado del problema que existe en la organización de enseñanza en términos de aprendizaje de lenguas extranjeras se muestra en este trabajo donde se 
analizan las políticas lingüísticas en el mundo, pero principalmente en Europa, Serbia y países de la ex Yugoslavia. La idea de aprender lenguas extranjeras a una edad temprana conlleva muchas dudas en cuanto a la adecuación de la enseñanza a los alumnos más jóvenes, el ajustamiento de los planes de estudio, así como los enfoques de métodos pedagógico-psicológicos. Uno de los mayores objetivos del trabajo es determinar si existe un plan de estudios adecuado para empezar con el aprendizaje de idiomas extranjeros desde el inicio de la escuela primaria y qué edad es la más adecuada para comenzar a aprender varios idiomas extranjeros. Se presenta un análisis de los modelos de enseñanza de países elegidos y de la ex Yugoslavia, pero se centra en el plan de estudios de los grados principales en las escuelas primarias de Serbia. En el estudio están incluidos los países multiétnicos y/o interesantes por su plan de estudios plurilingüísticos y su cercanía territorial con Serbia, que están presentados por sus modelos de enseñanza y métodos de aprendizaje de idiomas extranjeros a una edad temprana de investigaciones similares. La parte principal del estudio representa los planes de estudios a través de los documentos oficiales formando parte de la política lingüística educativa en Serbia, con la introducción sobre el aprendizaje de múltiples lenguas. Como resultado del estudio se puede concluir que se necesita una evaluación adicional y desarrollo de la docencia, pero también que ya está en un buen camino de progreso curricular, mientras que para el inicio del aprendizaje de una lengua extranjera se puede tomar como el período más adecuado entre el primer y segundo grado de la escuela primaria. Otros estudios en el futuro podrían incluir otros países con el multilingüismo desarrollado.

\section{Palabras claves:}

multilingüismo, educación primaria, política de educación lingüística

Summary

\section{TEACHING FOREIGN LANGUAGES AT AN EARLY AGE: OVERVIEW OF TEACHING MODELS AND CURRICULA IN SERBIA}

In this paper we have presented the ways of teaching foreign languages in the world, but primarily in Europe, Serbia and in the countries of the former Republic of Yugoslavia. One of the main goals of the paper is to determine whether there is an appropriate curriculum for young learners (those who are at the beginning of their primary school education) and what age exactly is the most appropriate. We have presented the analysis of the teaching models of selected countries around the world and those of the former Yugoslav Republics. The main part of the paper is an overview of curricula based on official documents within the language education policy of Serbia at the primary education. In conclusion, we suggest that teaching of foreign languages should be improved, 
but also the development of curricula is on the right track, while the period between the first and second grades of primary school can be considered most suitable for the beginning of foreign language learning. Further research could include other contexts where multilingualism is present.

\section{Key words:}

multilingualism, primary education, language education policy

\section{Додатак}

\section{Корпус: Наставни планови, програми и решења}

Ministarstvo prosvjete Crne Gore (2017). Rješenje o utvrđivanju opšteg dijela javno važećeg obrazovnog programa za osnovno obrazovanje i vaspitanje (na osnovu člana 22 stav 2 Opšteg Zakona o obrazovanju i vaspitanju i člana 196 stav 1 Zakona o opštem upravnom postupku). Službeni list RCG, br. 64/02, 60/03, 31/05, 49/07, Službeni list CG, br. 45/2010, 32/2011, 45/2011, 36/2013, 39/2013, Odluka nacionalnog savjeta za obrazovanje, 04-5-442/1. Podgorica: Zavod za školstvo.

Министарство просвјете и културе (2014). Наставни план и програм за основно образоваюе и васпитаюе. Републички педагошки завод Републике Српске Источно Сарајево: Завод за уџбенике и наставна средства.

Министарство просвјете и културе (2019). План и програм образовноваспитног рада у првом разреду основне школе. Републички педагошки завод Републике Српске.

Ministarstvo za izobraževanje, znanost in šport (2014). Predmetnik osnovne šole. (Predmetnik je bil sprejet na 23. seji SSSI, dne 17. 12. 1998 in usklajen s spremembami ZOŠ $(2011,2012)$, na 153. seji SSSI, dne 13. 12. 2012 ter usklajen s spremembami ZOŠ (2013), na 162. seji SSSI, dne 13. 2. 2014). Uradni list RS, št. 20/2014. Slovenija.

Министарство за образование и наука (2017). Решение за утврдуване на Наставен план и наставни програми за воспитно-образовната дејност во основно училиште во кеошто се реализира Мегуународна програма за основно образование (врз основа на член 55 став 1 од Законот за организација и работа на органите на државната управа и член 44-а од Законот за основно образование). Службени весник на Република Македонија, 6р. 58/2000, 44/2002, 82/2008, 33/2010, 116/2010, 167/2010, 156/2010, 18/2011, 51/2011, 6/2012, 100/2012, 24/2013, 41/2014, 116/2014, 135/2014, 10/2015, 98/2015, 145/2015, 30/2016, 127/2016. Скопље: Биро за развој на образованието.

Ministarstvo znanosti, obrazovanja i športa (2006). Nastavni plan i program za osnovnu školu (temeljem čl. 22. Zakona o osnovnom školstvu). Narodne novine, br. 59/1990, 26/1993, 27/1993, 29/1994, 7/1996, 59/2001, 14/2001, 76/2005. Hrvatska. 


\section{Правилници}

Министарство просвете, науке и технолошког развоја. Правилник о наставном плану за други циклус основног образоваюа и васпитаюь и наставном програму за пети разред основног образована и васпитаюа. Службени гласник РС - Просветни гласник, бр. 6/2007, 2/2010, 7/2010, 3/2011, 1/2013, 4/2013, 11/2016-I, 11/2016-II, 6/2017, 8/2017, 12/2018, 15/2018.

Министарство просвете, науке и технолошког развоја. Правилник о наставном плану за први циклус основног образоваюа и васпитаюа и наставном програму за први разред основног образовања и васпитаюа. Службени гласник РС - Просветни гласник, бр. 10/2017, 12/2018, 15/2018.

Министарство просвете, науке и технолошког развоја. Правилник о наставном плану за први, други, трећи и четврти разред основног образована и васпитань и наставном програму за трећи разред основног образована $u$ васпитаюа. Службени гласник РС - Просветни гласник, бр. 1/2005, 15/2006, 2/2008, 2/2010, 3/2011, 7/2011-I, 7/2011-II, 1/2013, 11/2014, 11/2016-I, 11/2016II, $12 / 2018$.

Министарство просвете, науке и технолошког развоја. Правилник о наставном програму за четврти разред основног образоваюа и васпитања. Службени гласник РС - Просветни гласник, бр. 3/2006, 15/2006, 2/2008, 3/2011, 7/2011-I, 7/2011-II, 1/2013, 11/2014, 11/2016-I, 11/2016-II, 7/2017, 12/2018. 